Pod koniec epoki brązu zachodniowielkopolskie społeczności kultury łużyckiej znajdowały się u szczytu rozwoju kulturowego, gospodarczego i zapewne demograficznego. Potwierdza to widoczna stabilizacja osadnictwa $w$ zajmowanych dotychczas ekumenach, wyrażona przede wszystkim ciagłością rozległych nekropolii, użytkowanych niekiedy nieprzerwanie od III EB, a przynajmniej od IV EB. Początki epoki żelaza nie doprowadziły do poważniejszych zmian strukturalnych w późnobrązowym systemie kulturowo-osadniczym. Wyroby z żelaza początkowo nie przewyższają liczebnie brązowych, a ich szersze rozpowszechnienie przypada dopiero na młodszy okres halsztacki (HaD). Depozyty datowane na $\mathrm{HaC}$ w zasadzie nie zawieraja przedmiotów żelaznych, które stosunkowo częściej spotyka się wówczas na cmentarzyskach, przy czym są to glównie ozdoby: szpile lub bransolety. Częstotliwość ich występowania wyraźnie wzrasta w miarę zbliżania się do Śląska środkowego, natomiast na terenach położonych na północ od środkowego biegu Obry (Pojezierze Poznańskie) początkowo jest raczej niewielka. Wydaje się, że tutaj adaptacja wzorów halsztackich następuje najpierw w metalurgii brązowej, a popularność żelaza wzrasta nieco później. Wskazuje to raczej na powolne recypowanie technologii obróbki nowego metalu i nowych trendów stylistycznych, przy częściowym zachowaniu wcześniejszych tradycji; analogiczne tendencje obserwujemy również w ceramice.

Proces halsztatyzacji, przebiegający $\mathrm{z}$ różnym natężeniem i pod wpływem niekiedy odmiennych ośrodków „przekaźnikowych”, doprowadził do rozpadu dotychczasowej grupy zachodniowielkopolskiej (brandenbursko-lubuskiej) i trwałego rozdziału ziemi lubuskiej (grupa górzycka) i zachodniej Wielkopolski (cześć grupy śląskiej). Jednak dokonującej się stopniowo zmianie oblicza kulturowego nie towarzyszyla dezintegracja dotychczasowego, dość prężnego już w V EB, systemu osadniczo-gospodarczego, który stał się podstawą pełnego rozkwitu społeczności zamieszkujących międzyrzecze Warty i Obry we wczesnej epoce żelaza.

Na zakończenie pragnę podkreślić, że późnobrązowe spoleczności zachodniowielkopolskie cechowal wysoki stopień rozwoju społeczno-kulturowego, którego zaledwie częściowym świadectwem są pozostające obecnie do dyspozycji źródła archeologiczne. Bardzo wyraźnie rysuje się stały kontakt tych populacji z ugrupowaniami śląskimi, najsilniej inspirującymi rytm i mechanizmy dokonujących się przemian kulturowych. Wydaje się, że wysoka pozycja zachodniej Wielkopolski w interregionalnej strukturze kultury łużyckiej wynikała w dużym stopniu właśnie z bliskiego sąsiedztwa ze środkowym Śląskiem. Nie przekreśla to jednak wysokiej aktywności kulturowo-gospodarczej lokalnych społeczności, a wręcz przeciwnie - akcentuje właściwe wykorzystanie sprzyjających, jak byśmy to dziś powiedzieli, „warunków geopolitycznych”.

Maciej Kaczmarek

\title{
OSADY KULTURY PRZEWORSKIEJ Z TERENÓW ZIEM POLSKICH
}

(autoreferat wygloszony w trakcie obrony pracy doktorskiej w dniu 2 lutego 2001 r.)

Podstawowym zagadnieniem prezentowanym w niniejszej pracy jest osada, czyli - jak to ujmuje Stownik języka polskiego: „miejsce będące skupieniem ludności osiadłej” bądź „nieduże skupienie budynków". W literaturze przedmiotu dość powszechnie uważano, iż osady pradziejowe nie miały zbyt regularnego układu zabudowań, jak też pól. Miały być one zbliżone wyglądem do dzisiejszych 
przysiólków. Na podstawie przeprowadzonych przeze mnie analiz stwierdzenia takie nie wydają się być do końca zgodne z prawdą. Zostały one oparte na obserwacjach 299 stanowisk osadowych związanych z kulturą przeworską. Są to wszystko osiedla, które były co najmniej rozpoznane sondażowo i na których stwierdzone zostało występowanie obiektów związanych z omawianym tutaj ugrupowaniem. Przedmiotowe stanowiska to wyłącznie osady opracowane i opublikowane, funkcjonujące już w literaturze archeologicznej. Stanowią one, niestety, tylko niewielki procent ogólnej liczby wszystkich badanych wykopaliskowo stanowisk osadowych omawianej kultury, lecz nie udostępnionych jak dotychczas w żadnej formie ogólowi badaczy; ten niewielki procent jest z kolei jakimś ułamkiem niemożliwej do określenia rzeczywistej liczby osiedli kultury przeworskiej istniejących niegdyś na terenie ziem polskich. Istotnym kryterium, które wpłynęło na taki a nie inny obraz stanu badań, było wzmiankowanie danego stanowiska w literaturze przedmiotu, choćby w postaci krótkiego komunikatu. Niestety, z ogólnej liczby 299 osiedli, tylko 40 doczekało się pełnego opracowania. Jest to zaledwie 13,4\% ogólu tychże osad. Spośród zebranych w mojej pracy stanowisk osadowych, tylko niewielki odsetek stanowiły osiedla, które zostały zbadane w sposób wystarczający do przeprowadzenia analizy ich rozplanowania. Eksploracje osad kultury przeworskiej prowadzone były bowiem $\mathrm{z}$ reguły na niewielkich tylko powierzchniach. Zaledwie 68 stanowisk rozpoznano szerokopłaszczyznowo, czyli na powierzchni - jak to przyjęto w pracy - od ok. 20 arów wzwyż, co daje co prawda około $27,7 \%$ ogólnej liczby stanowisk, ale opracowania doczekały się tylko 22 z nich, czyli około 7,4\%. Te właśnie osady stanowią podstawową bazę źródłową moich rozważań.

Na obraz zewnętrzny osiedla sklada się:

- położenie w obrębie sieci okolicznych osad (liczba i wielkość osiedli w stosunku do zajmowanego terenu i sposób ulokowania się w nim),

- rozplanowanie pól danej osady,

- rozplanowanie osady (sposób rozlokowania poszczególnych gospodarstw),

- zabudowa osady (stan, rodzaj i typ budynków oraz ich przeznaczenie).

Niestety, wielu z wymienionych tutaj elementów w przypadku osiedli kultury przeworskiej nie jesteśmy w stanie zaobserwować. Przede wszystkim bardzo trudno odtworzyć pełną sieć osad, gdyż tylko wyjątkowo możliwe jest zbadanie w całości obszaru, na którym funkcjonowało dane ugrupowanie kulturowe. Elementem, który można uchwycić najłatwiej i który starałem się uwypuklić w mojej pracy, jest sposób lokowania osady w terenie, jej przystosowanie do zastanych warunków geomorfologicznych. Ukazanie rozplanowania pól w okolicach osiedla pradziejowego, przy uwzględnieniu destruktywnej intensywności rolnictwa nowożytnego, na ziemiach polskich jest w zasadzie niemożliwe. Elementem możliwym do odtworzenia, ale tylko w wypadku badań szerokopłaszczyznowych, jest rozplanowanie wsi. W zasadzie jednak stan rozpoznania wykopaliskowego osad oraz stan ich opracowania i opublikowania nie dają podstaw do rekonstrukcji struktury wewnętrznej osiedla, co w moich rozważaniach zawęziło ten aspekt analizy tylko do nielicznych osad. Zabudowa, ostatni element obrazu zewnętrznego wsi, w wypadku osiedli pradziejowych jest niejednokrotnie trudna do rozpoznania. Ślady domostw zrębowych są możliwe do uchwycenia tylko zupełnie wyjątkowo bądż też są całkowicie nieczytelne. Domy słupowe naziemne można zaobserwować dość wyraźnie, aczkolwiek również tutaj przy wyznaczaniu ich zarysów pojawić się mogą pewne trudności, gdy mamy do czynienia z większą ilością i zagęszczeniem dołków posłupowych. Najbardziej bezsporne są pozostałości domostw zagłębionych - półziemianek i ziemianek. Analiza przeznaczenia poszczególnych budynków ma często charakter wyłącznie „intuicyjny”, np. obecność lub brak paleniska przesądza o tym, czy budynek zaliczany jest do mieszkalnych, czy gospodarczych. Nietypowe położenie domostwa (centralne, peryferyjne) bywa niekiedy przesłanką do przypisywania mu specjalnej, często kultowej funkcji. W odniesieniu do zabudowy możemy czasami znaleźć w trakcie badań ślady mówiące o naprawach danego budynku. Jest to także jakaś wskazówka tycząca „technicznego stanu” osady. W swojej pracy nie zaj- 
mowałem się typologią budynków, skupiając się wyłącznie na analizie samej struktury osiedla i jego położenia. Pominięty aspekt stanowi sam w sobie temat do odrębnych badań.

Ludność kultury przeworskiej nie wytworzyła innego typu formy osadniczej niż otwarte osiedle typu wiejskicgo. Nawet funkcjonujące w ramach tego ugrupowania osady produkcyjne utrzymują ten charakter. Na żadnej ze zbadanych osad nie zostały stwierdzone jakiekolwiek pozostałości po grodzeniu obszaru wsi bądź jakichś systemów umocnień. Osiedla te nie miały zatem nigdy charakteru obronnego. Brak zamknięcia obszaru osady pozwalał na jej swobodny rozwój i łatwe przesunięcia zabudowy, widoczne $w$ poszczególnych fazach chronologicznych. Wieś kultury przeworskiej nie była wyłącznie niezorganizowanym zbiorowiskiem domostw mieszkalnych, budynków oraz obiektów gospodarczych. Owszem, występują wśród osiedli tego ugrupowania także przykłady zabudowy bezładnej, jednak w znacznej mierze chodzi tu o osady budowane planowo, $z$ wyraźnym podziałem na strefy mieszkalną, produkcyjną i gospodarczą. Zdarzało się, iż owe części: gospodarcza i mieszkalna, przenikały się, tworząc jedną zwartą strefę. Działo się tak głównie w przypadku osiedli produkcyjnych, na których wyspecjalizowane urządzenia wytwórcze „,spychały" w głąb osady obiekty związane z codziennym życiem wsi.

W ukladzie zabudowy osad kultury przeworskiej widać już funkcjonowanie pewnych modeli wiosek. Są to - według określenia K. Moszyńskiego - starsze typy wsi zwartych. Większość takich osiedli kultury przeworskiej można zaliczyć do okolnic, które jeszcze w początkach XX w. były popularne na pograniczu słowiańsko-germańskim. Do tej kategorii zaliczane są wszystkie wsie rozlokowane wokól centralnego placu, względem którego ulożona była promieniście cała zabudowa osiedla. Występowaly one powszechnie w większości centrów osadniczych kultury przeworskiej, poczynając od okresu przedrzymskiego po okres wędrówek ludów. Takie ich rozplanowanie było najbardziej typowe dla niewielkich osiedli z okresu późnorzymskiego, choć poszczególne fazy dużych osad o długiej chronologii charakteryzował podobny układ. Mimo iż okolnice wydają się być zjawiskiem dość powszechnym, to jednak prawdopodobnie dominują w zachodniej części terenów zajętych przez ludność kultury przeworskiej, zwlaszcza na Śląsku i w Wielkopolsce oraz Polsce centralnej.

Drugi pospolity w tym ugrupowaniu kulturowym typ osiedla wiejskiego to ulicówka, a w zasadzie jej wariant ciągnący się wzdłuż krawędzi brzegu rzeki. W przypadku osiedli kultury przeworskiej mamy zapewne do czynienia nie z klasyczną ulicówką gdzie domy stały blisko siebie wzdłuż drogi, a obiekty gospodarcze znajdowały się na ich zapleczu, lecz z rzędówkami, różniącymi się od ulicówek większym rozproszeniem domów. Tego typu osiedla powszechne były we wschodniej strefie kultury przeworskiej. Występowały one głównie na Mazowszu (prawobrzeżnym) oraz w Małopolsce zachodniej, a sporadycznie również poza tymi centrami osadniczymi. W okresie wędrówek ludów nad górną Wartą pojawiają się wsie przypominające układem owalnice. Ten typ osiedla wiejskiego miał powstać w wyniku fuzji okolnicy i ulicówki. Od typowych owalnic różni je jedynie to, iż na osiedlach kultury przeworskiej z V w. n.e., które widzimy w Polsce centralnej, zamiast dwóch rzędów domostw wystapiły od czterech do pięciu.

Powyższe rozróżnienie ma cele ściśle klasyfikacyjne. Nazwy wymienianych tutaj poszczególnych typów wsi, a także kryteria przyjęte do ich klasyfikacji, odnoszą się - rzecz jasna - do osad wiejskich w pełni rozwiniętych, powstałych w średniowieczu, w wyniku kolonizacji. Rozplanowanie osiedli kultury przeworskiej nie wiązało się z tak surowymi rygorami jak te, które formowały oblicze wsi europejskiej w dobie średniowiecza. Ich kształt nie zawsze jest zatem w pełni wyraźny, przez co odbiega czasami od kanonów danego typu. W większości przypadków o wyglądzie osiedla omawianej kultury decydowaly zapewne lokalne warunki terenowe, co - jak podkreśla J. Burszta - widać jeszcze obecnie na przykładach wiosek, które zachowały swój charakter przedkolonizacyjny. Mamy tu prawdopodobnie do czynienia z zaczątkami wzmiankowanych powyżej układów przestrzennych, które w następstwie mogły się z nich rozwinąć. 
Obok osad, które można zakwalifikować do prototypów nowożytnych osiedli wiejskich, na terenie objętym osadnictwem kultury przeworskiej występowały także osady reprezentujące osadnictwo rozproszone, jak wzmiankowane przeze mnie osiedla jednodworcze, a także takie, które trudno przyporządkować dzisiejszym klasyfikacjom. Sa to wszelkie osiedla z chaotyczną, rozproszoną zabudową bądź składające się z luźnych zagród, nie tworzących czytelnych układów. Być może chodzi tu o formę przejściową od osadnictwa rozproszonego do wsi zwartych. Stanowią one zapewne najstarszą formę osady w kulturze przeworskiej.

Najważniejszym z czynników mających wpływ na lokalizację osad kultury przeworskiej były warunki naturalne. Obserwuje się w tym zakresie wyraźne preferencje, które są niezmienne, niezależnie zarówno od fazy chronologicznej, jak i centrum osadniczego. Podstawowym warunkiem wydaje się być bliskość wody, a zwłaszcza rzeki - z niewielu wyjątkami ulokowanymi nad brzegami jezior (jak np. Ołobok czy Polanowice), pozostałe osady kultury przeworskiej położone były nad rzekami. Bardzo często wybierano takie miejsca, gdzie mniejsze cieki wpadaly do większych rzek. Zapewniało to nieustanną dostawę świeżej wody; położenie nadrzeczne ułatwiało zapewne również komunikację $z$ innymi ośrodkami tego ugrupowania. Rzeki, takie jak np. Odra ze swoimi dopływami, tworzyły naturalną sieć komunikacyjną. Odkrycia lodzi potwierdzają dodatkowo istotną rolę rzek. Osiedla starano się chronić przed sezonowymi wylewami rzek. W tym celu lokowano je na rozmaitych eksponowanych, wyniesionych ponad podtapiana strefę formach terenowych. Jak dokuczliwe musiały być te zalewy, świadczy choćby ślad po nasypie ziemnym wzniesionym w najniżej położonej części osady w Kobylnikach, będącym najprawdopodobniej wałem przeciwpowodziowym. Położenie na danej formie terenu (krawędź terasy nadzalewowej, wzgórze, cypel itp.) nie pozostawało zapewne bez wpływu na rozplanowanie osiedla. Mimo iż lokowane były one w zbliżonych warunkach naturalnych, to jednak wyraźne jest preferowanie w pewnych regionach takiego a nie innego typu zabudowy, co musiało mieć już uwarunkowania pozaśrodowiskowe, kulturowe.

Reasumując można stwierdzić, że obraz osad kultury przeworskiej wynikający z ich „etnograficznego" oglądu zdaje się sugerować pewne prawidłowości widoczne na całym przedmiotowym obszarze. Widoczne jest współdzialanie przy ich powstawaniu i kształtowaniu czynników zarówno natury środowiskowej, jak i kulturowej. Te pierwsze są istotne dla wszystkich okresów, jak i centrów osadniczych omawianego ugrupowania. Związane są z preferowaniem przez ludność tej formacji określonego ekosystemu. Te drugie są efektem wewnętrznego rozwoju kultury przeworskiej, wierzeń, kształtowania się lokalnych tradycji oraz czynników gospodarczo-ekonomicznych. To właśnie owe czynniki kulturowe wpłynęły wyraźnie na wykształcenie się zróżnicowanych form rozplanowania przestrzennego osiedli ludności kultury przeworskiej. Paradoksalnie, stanowiły one także pewnego rodzaju mechanizm unifikacyjny, jeśli spojrzeć na globalną strukturę wsi omawianego ugrupowania. Czynniki kulturowe zdają się być odpowiedzialne za wyodrębnienie się przynajmniej dwóch stref dominacji określonego układu przestrzennego. Chodzi tutaj o upowszechnienie się osiedla placowego (okolnicy) bądź też rzędowego (ulicówki). Także one mają jak się wydaje, wpływ na upowszechnianie się w pewnym momencie osad rozproszonych, jednodworczych, będacych efektem zapotrzebowania na nie $w$ związku z przesunięciami ludnościowymi zachodzącymi w kulturze przeworskiej. Na osiedlach z okresu przedrzymskiego i z okresu wpływów rzymskich nie obserwujemy wyraźnego konfliktu pomiędzy uwarunkowaniami naturalnymi i kulturowymi osadnictwa. Widoczne jest tutaj dostosowanie się osad do zastanej sytuacji geomorfologicznej, przy zachowaniu pewnych określonych wzorców rozplanowania sankcjonowanych kulturowo.

W związku z powyższym, na podstawie obecnego stanu badań, obraz osiedla kultury przeworskiej jawi się jako stabilny i mimo pewnego zróżnicowania jednorodny. Model wsi jest w pełni dopasowany do preferowanych przez to ugrupowanie warunków środowiskowych. Poszczególne osiedla są przystosowane do funkcji, jakie mają pełnić, czemu służy struktura rozplanowania ich przestrzeni. Tradycja kulturowa działa tutaj jako czynnik stabilizujący i ujednolicający, a zarazem 
dostosowujący formę osady do sytuacji jednostkowej. Powoduje to, iż mimo szerokich ram chronologicznych kultury przeworskiej oraz różnorodności obszarów, które znalazły się pod kontrolą jej ludności, osady zachowują w miarę jednolity kształt, wkomponowany w preferowane przez nią warunki geomorfologiczne.

Niestety, jak podkreślałem już we wstępie mojego wystapienia, osiedla, które zostały poddane analizie przestrzennej i mogły dostarczyć bardziej wartościowych danych na temat ich rozplanowania i struktury, stanowią tylko znikomy procent ogółu osad. Dopiero lepsze rozpoznanie tego typu stanowisk pozwoli w przyszlości uzyskać pełniejszy obraz omawianego zagadnienia. Im większą bazą danych będziemy dysponować dla tej problematyki, tym jaśniejszy i pewniejszy stanie się obraz osiedli z młodszego okresu przedrzymskiego i okresu wpływów rzymskich oraz wędrówek ludów wiązanych z kulturą przeworską.

Andrzej Michatowski

\section{LAS W KULTURZE ŚREDNIOWIECZNEJ WIELKOPOLSKI}

(autoreferat wygloszony $w$ trakcie obrony pracy doktorskiej

w dniu 3 grudnia 1999 r.)

Tematem niniejszej pracy jest las w kulturze średniowiecznej Wielkopolski, postrzegany głównie przez pryzmat człowieka i jego działalności gospodarczej. Jest to temat szeroki, swoją problematyką obejmujący pogranicze kilku nauk. Przede wszystkim archeologii, gdyż podstawowy materiał badawczy pochodził właśnie z wykopalisk archeologicznych, oraz etnografii, która stanowiła punkt odniesienia do rozważań nad duchowymi, ale również i materialnymi aspektami kultury. Wykorzystano także pewne elementy paleoekologii, w tym głównie te związane z palinologią leśnictwem i technologią drewna.

Praca składa się z trzech podstawowych części. Tematem pierwszej jest rola lasu w środowisku naturalnym, m.in. wpływ na kształtowanie się klimatu, pokrywy glebowej, a także jego funkcje ochronne, zwiazane z przeciwdziałaniem erozji wietrznej i wodnej gleby. Starano się uwypuklić te elementy, które byly związane z działalnością ludzką lub też na nią wpływały.

W czéści drugiej zajęto się gospodarczymi funkcjami lasu, takimi jak: lowiectwo, zbieractwo i bartnictwo. Z części tej dodatkowo wyodrębniony został rozdział odnoszący się do kierunków wykorzystywania surowca drzewnego. Celem takiego układu pracy było dodatkowe wyeksponowanie podstawowego materiału badawczego, a stanowily go oznaczenia taksonomiczne prób drewna i węgli drzewnych ze stanowisk wielkopolskich, datowanych szeroko od wczesnego średniowiecza aż po początek czasów nowożytnych. W niewielkim stopniu, głównie dla pokazania niezmienności pewnych rozwiązań, sięgnięto po starsze i młodsze analogie. W rozdziale tym starano się prześledzić specyfikę doboru surowca drzewnego, przede wszystkim w zależności od funkcji, ale także i techniki produkcji, co pozwoliło określić, przynajmniej w pewnym stopniu. stan poznania przez ówczesne społeczeństwo właściwości technicznych drewna oraz umiejętności ich celowego wykorzystywania.

Stan badań nad wykorzystywaniem surowca drzewnego jest nierównomierny, w niektórych kategoriach wytworów jest on dobry, w innych daleko niedostateczny. 